\title{
SIR WILLIAM BLIZARD AND HIS POEMS
}

by

\author{
R. M. S. McCONAGHEY, M.D.
}

A sLim leather-bound volume has recently come into my hands.* On its back is stamped in gold letters 'Blizard-Poetry'; its contents are in manuscript. In faded brown ink each poem is indited in handwriting of varying excellence. There are ninety numbered pages to the manuscript, but pages $67-70$ have been cut out. The heraldic bookplate of F. A. Curling is inserted in the cover.

Included in the list of contents are two odes commemorating the anniversaries of the London Hospital, and another the first charter granted to the College of Surgeons. A memoir of Sir William Blizard, F.R.s., follows, signed T.B.C. These initials stand for his nephew Thomas Blizard Curling appointed in 1833 at the early age of twenty-two as Assistant Surgeon to the London Hospital. This brief memoir is derived from the address published in 1835 and read before the Hunterian Society by William Cooke, its secretary.

Contracted into two and a half pages, the memoir contrives to pay tribute to the immense enthusiasm and general benevolence of the author, but gives little biographical information about a character whose long life covered an important period of medical history and to whose work as a medical teacher posterity owes a very real debt.

Born in 1743 , son of an auctioneer, William Blizard was apprenticed to a surgeon at Mortlake and later attended the lectures of Pott at St. Bartholomew's Hospital, and of John Hunter at the Society he ran at Leicester Field. He also studied at the London Hospital to which charity he was appointed surgeon in I 780. ${ }^{1}$ When Lettsom founded the Medical Society of London in I 773, Blizard was one of the founder members, and thirty years later he, with others, seceded from that society to found the Medical and Chirugical Society, now the Royal Society of Medicine. ${ }^{2}$

As quite a young man he associated with a Dr. Maclaurin, a teacher of anatomy, in giving lectures on surgery at a small house in Thames Street and afterwards in Mark Lane. ${ }^{3}$ In I78I he gave lectures on anatomy and surgery at the London Hospital, but had to promise, before the committee of the hospital granted permission, that he would not use any patients of that hospital in his demonstrations. ${ }^{4}$ This must have been a hardship, for we read that Blizard was a bad lecturer but an excellent teacher. ${ }^{5}$ According to Garrison this private school became the London Hospital School of Medicine in 1785 , and was the first school of its kind to be formed in the metropolis. ${ }^{6}$ Blizard was appointed Professor of Anatomy to the Surgeons Company in 1787 and delivered the customary three lectures. It is recorded in the company's minutes

\footnotetext{
* This volume has since been presented to the Hunterian Society by Mr. Wyndham Paine, its previous owner. I am indebted to Mr. C. Robert Rudolf, Hon. Curator of the Hunterian Society, for considerable help in the preparation of this paper.
} 


\section{Sir William Blizard and His Poems}

that the thanks of this court be given to Mr. Professor Blizard for his three ingenious practical and instructive lectures on anatomy and surgery delivered upon this occasion and that a minute be made of this resolution by the Clerk

-a resolution which was carried unanimously and is the only one of its kind in the company's records. ${ }^{7} \mathrm{He}$ took an active part in the councils of the Surgeons Company right up to the time of its dissolution. He and Cline were appointed to join with the Masters and Wardens of the Company in their negotiations with the Trustees of John Hunter for the reception of his museum, ${ }^{8}$ and according to Bland-Sutton he himself was the owner of a museum of his own making ${ }^{9}$-thus following in the footsteps of his friend and teacher the great John Hunter. The story is told by Stephen Paget of a dinner party given by Hunter during which Blizard had to make the excuse of a whitlow to ward off the pressing invitations of Hunter to drink his wine. John Hunter was, for the times in which he lived, a fairly abstemious man. ${ }^{10}$ His long life extended long after Hunter's death, into a generation by whom the great surgeon was clearly regarded with veneration. He described John Hunter to Marshall Hall as rather sandy complexioned with a keen eye and a slight stoop. 'Indeed I should say he was a little man.'11 Blizard later became the first President of the Hunterian Society.

The London Hospital was, as we have already noted, the first hospital in the metropolis to have a medical school attached to it. In 1783 the physicians and surgeons petitioned the governor to build, at the cost of $£ 600$, a 'proper building' for the teaching of the several branches of physic and surgery by lectures at the hospital, and Blizard issued an appeal in pamphlet form-'An Address to the Friends of the London Hospital and of Medical Learning'-for the subscription of funds. ${ }^{12}$ With the help of liberal gifts from himself this appeal was successful and 'the London' started on its long career as a teaching hospital.

Abernethy, who attended his earlier lectures, was warm in his praises. In his opening lecture as Professor of Anatomy and Surgery at the Royal College of Surgeons in 1814, Abernethy says:

he displayed to us the beau ideal of the medical character. I cannot readily tell you how splendid and brilliant he made it appear; and then he cautioned us never to tarnish its lustre by any disingenuous conduct, by anything that wore even the semblence of dishonour. 'Let your search after truth [he would say] be eager and constant. Be wary of admitting propositions as facts before you have submitted them to the strictest examination. If after this you believe them to be true, never disregard or forget one of them. Should you perceive truths to be important, make them the motives of action, let them serve as springs to your conduct.'

Here, indeed, an apostle of John Hunter speaks. ${ }^{13}$

Lettsom in introducing his 'Hints respecting a Samaritan Society' in I80 I expresses a 'singular pleasure' in classing him amongst the number of his friends and refers to him as 'a character that happily unites science with benevolence and professional skill with the exercise of humanity'.14

Blizard was always scrupulous in his attention to his duties as a surgeon, but was often ridiculed for the importance which he attached to learned diction and 


\section{R. M. S. McConaghey}

ceremonial observance. ${ }^{15}$ This trait was parodied in the Lancet in 1833 in the 'Gallery of Medical Portraits' ${ }^{16} \mathrm{He}$ is said to have replied to a student who during a ward round suggested a patient should be tapped-'pray what publican was you brought up under?' 'Do pray mark this gentlemen. Always say Paracentesis abdominis; Paracentesis scroti.' It is to be feared that in spite of the high esteem that Abernethy had of him, he was not a universally popular figure. A note appended to a manuscript letter of his in the Wellcome Library -in an effort, it would seem, to belittle him-describes him as the son of a barber at Barnes. He was, we learn from the same source, dreaded by the students as an examiner. $\mathrm{He}$ is described as high-spirited, ill-tempered and daring. 'He once lept from his carriage and seized a highwayman by the throat; and it is not long since he challenged one of his colleagues at the hospital to mortal combat.' Twice he was President of the College of Surgeons, and the story is told of him attending in that capacity at their premises in Cock Lane in full court dress to receive from the hangman the bodies of executed criminals. 'The contrast between the President's elaborate costume with the formal manner and surly shabbiness of the executioner is described by Sir R. Owen as "having made a ghastly scene almost ludicrous".'17

He was among the last to carry on the fast-dying custom of attending patients and giving advice to apothecaries and colleagues in coffee-houses. There is a portrait of him in the Royal College of Surgeons which shows a man of singular character, clear straight gaze, roman nose, firm mouth and a well-formed lower jaw. A period drawing by H. G. Clift in the British Museum shows a kind, dignified face of firm character. The writer of the anonymous note quoted above comments: 'if ever coutenance announced a snarler it is that of Sir William Blizard!' He was elected F.R.s. in 1787 and was knighted in 1803 . He continued to operate until he was eighty-four and lived to the age of ninety-three. When ninety-one he underwent a successful operation for cataract, performed by Sir William Lawrence ( $1783-1867$ ) to whom he gave a gold snuff-box to commemorate the occasion. ${ }^{18}$ Blizard wrote little on medicine that was of permanent interest, but a popular lecture 'On the Situation of the large Blood Vessels of the Extremities; and the Methods of making effective Pressure on the Arteries, in cases of dangerous effusion of Blood from Wounds' ran into several editions. It is an attempt to teach first aid to sailors, together with a plea for a more general cultivation of the subject. I introduce his prefatory remarks as an example of his style:

Were the knowledge of the situation of the blood vessels of the extremities, so far as is necessary for checking dangerous effusions of blood, and the use of the tourniquet more general; not confined to the navy and army but extended to colleges and schools particularly military and nautical academies, manufacturies, hospitals of every description, prisons, plantations, fire-officers, the clergymen of parishes in which no surgeons are resident, commanders of merchantmen, mines, etc., it could not fail of proving highly beneficial to mankind.

Of his poetry Moore ${ }^{17}$ somewhat unkindly remarked that had he been longer a contemporary of Pope he would undoubtedly have qualified for a place in 


\section{Sir William Blizard and His Poems}

the 'Dunciad', and Sir William Mac Cormac refers to him as having been addicated to the writing of mediocre vers d'occasion. For us today, however, these casual effusions have an interest greater than the mere quality of the verse. The first item has an almost modern ring; it is addressed

To Busick Harwood M.D. Prof. Anat, Cantab: F.R.s. \& c, on reading an account of his experiments in transfusing the blood of one animal into another nearly exhausted.

$$
\begin{aligned}
& \text { If when the springs of life shall fail, } \\
& \text { New sources by thy art, avail } \\
& \text { To move again the trembling frame, } \\
& \text { Immortal honour waits thy name. } \\
& \text { And virtue, wisdom, by thy care } \\
& \text { Shall flourish with the lives you spare. }
\end{aligned}
$$

The experiments on blood transfusion of Lower, Boyle, Wren and Pepys are well known. It is true also that in I 760 Mackenzie theorized on the benefits to be derived from the measure, ${ }^{19}$ and Blizard's poem reminds us that there were others in the field, although defibrinated blood was not used till 1825 .

It is refreshing after reading so much about the coarseness of the medical students of the time to read the lines in memory of Mr. Michael Pearson, Jnr., a favourite pupil at the London Hospital, who died 23 April I 79I at Cowes in the Isle of Wight, aged twenty-two:

His happy soul! like the pure lambent flame

Shone sweetly through its tenemental frame;

A brilliant star! held from its native sphere;

Admir'd, belov'd, awhile he dazzl'd here.

There follows an elegiac monody on the death of Louis XVI, another on the death of the Queen of France; two hymns to be sung on the anniversaries of the London Hospital on 18 April I 792, a number of short pieces and a set of seven riddles the answer to one of which is the London Hospital; and on other miscellaneous subjects.

On page 72 there is a note to the effect that 'it became the author's practice to write the following soliloquies on the Ist March'. This was his birthday, and it is in these later poems that Blizard reveals something of himself. In 1826 when he was eighty-three-a year before he ceased to operate in the hospital -he wrote the following 'lines occasioned by some unusual expressions of the pulse'. He had indeed experienced for the first time at so late an age the dropping of heart-beats (extra-systoles) which is a regular accompaniment of increasing years. It is a poignant piece:

Long time hath beat this anxious heart Propell'd life's current through the frame; Sustain'd each organ's distin'd part;

And breath'd o'er all, health's gentle flame. 


\section{R. M. S. McConaghey}

Poor heart! at length art weary grown?

Else, why the wonted throb suspend?

Or, why the pulse with feeble tone?

Or, what alas! these signs portend?

I know; nor will disturb thee more!

Calmly await thy resting day

Grateful! - to Heaven the mind shall soar;

And cease to muse on vital clay.

In his soliloquy for I March 1832 he refers 'in figurative strain' to the great cholera epidemic of the previous year; an epidemic which had spread through the country, dealing devastation and death in its path. Next year he is rather pathetically wondering at the length of his life. He is now eighty-nine and he refers to one 'Henry Jenkins of Bolton-upon-Swale in Yorkshire the time of whose death is not exactly recollected; [who] died at the age of I69 years'. Nowhere does he refer to the onset of his blindness, but in the last soliloquy he refers to the recovery of his sight in lines which show no sign of the weakness of old age:

Long time I pass'd the gloomy, lingering day, Passive expectant of a visual ray.

But now, the morning dawn, the moon's calm light, Rejoice my soul, and pious strains excite,

The mind invokes, and light's reflective ray

To visual sense, will forms defin'd convey.

The sight, in contemplation's proper scope,

Advances science, strengthens Christian hope.

All nature spreads her charms to ravish sight;

And truth unfolds; long hid in shades of night;

O'er ev'ry sense, its gleams attractive rove:

It aids the toil, which virtuous hands approve.

It bids creative fancy take the wing;

Whence, countless forms, in airy phantoms, spring;

It fathoms earth's recesses, ocean's pride;

And kens the treasure, rock and mountain hide.

From its sole glance are new ideas form'd;

Fertile as those which Shakespeare's genius warm'd.

After discussing at length the benefits of eyesight he describes the compensations of the blind:

Discriminations often thence, arise;

Source to the blind of pleasure, and surprise.

The rose and lily, od'rous charms diffuse;

The sense of touch, its objects to explore,

Is Man's best friend, when light is felt no more:

O'ft have I wander'd long a fav'rite way,

By feel alone, of straggling sprig or spray:

$$
296
$$




\section{Sir William Blizard and His Poems}

A robe of silken web, and snowy hue

Has oft been recognised with judgement true.

Can auditory sense, sublimly rise,

And hail seraphic minstrel in the skies?

Or who, with Handel's spirit in the choir,

When the deep organ bursts with Sampson's fire

Would not exclaim-Am I on native earth?

Then he gives thanks for the blessing of sight regained:

Hush! bless'd impress! sight suddenly restor'd!

Prostrate, I breathe thanks-giving, gracious Lord!

The face of nature, sun-gilt world, to see

Revives each fibre's sense of function free,

But I will not the loss of sight deplore;

Its restoration animates the more.

It is not perhaps great verse, but it is a record of the sensations of a great man who has experienced one of the greatest trials that man is heir to. As such it is of value.

At the time that Blizard died, the apprentice system was still in full use, but the education of a student was not regarded as complete without a spell spent in walking the wards of a teaching hospital. It was this innovation that was Sir William Blizard's capital achievement.

\section{REFERENCES}

I. Moore, Sir Norman, Dict. Nat. Biog.; 1886, v, 223.

2. Fox, R. Hingston, Dr. Fohn Fothergill and His Friends, London, 1919, pp. 153, 155.

3. Morris, E. M., A History of the London Hospital, London, 1926, p. I31.

4. Ibid., p. 175 .

5. Ibid., p. 132 .

6. Garrison, F. H., An Introduction to the History of Medicine, Philadelphia, 1929, p. 399.

7. W All, C., The History of the Surgeons Company 1745-1800, London, 1937, pp. 105, 161.

8. Ibid., p. 114 .

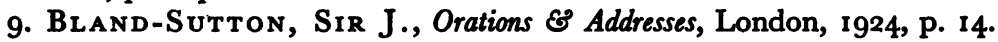

10. Paget, Stephen, Fohn Hunter, London, 1897, p. 221.

11. Mac Cormac, Sir William, An Address of Welcome, London, 1900, p. 57.

12. MORRIs, op.cit., p. 173 .

13. Pettigrew, T. J., Medical Portrait Gallery, London, 1838-40 II, p. 2.

14. Letrsom, John Coarley, Hints Designed to promote Beneficence, Temperance and Medical Science, London, 1901, II, 4.

15. Lancet, 1834, III, 19.

16. Lancet, $1833, \mathrm{II}$.

17. MOORE, op. cit., p. 223.

18. Mac Cormac, op. cit., p. 55 .

19. Magkenzie, James, $A$ History of Health, Edinburgh, 1758, p. 431 . 